\title{
Early Paleozoic brachiopod larva: true larva, not a juvenile
}

\author{
Anna A. Madison ${ }^{1}$, Tatyana V. Kuzmina ${ }^{2}$ \\ ${ }^{1}$ Borisyak Paleontological Institute, Russian Academy of Sciences, Profsoyuznaya ul. 123, Moscow, \\ Russian Federation, 117997. E-mail: sunnyannmad@yahoo.com \\ ${ }^{2}$ Lomonosov Moscow State University, Biological Faculty, Dept. Invertebrate Zoology, Leninskie \\ gory 1, Russian Federation, 119991.E-mail: kuzmina-t@yandex.ru
}

ABSTRACT: The ontogeny of extinct brachiopods is often reconstructed from specimens with well-preserved juvenile shells. However, paleontological reconstructions based on the fossil material contradict the reconstruction of the evolution of brachiopod life cycles based on the analysis of the ontogeny of recent brachiopods. If the paleontological reconstructions suggest a planktotrophic stage with a shell as the initial type of the brachiopod ontogeny, the biologists suppose true planktotrophic larva to be the basic stage of the brachiopod life cycles. In the present paper, the paleontological data are considered in correspondence with the data on the different developmental stages of recent brachiopods. The large size and presence of the impressions of larval setal sacks are interpreted as evidence of the stage of true planktotrophic larva in the ontogeny of the Early Paleozoic brachiopods.

How to cite this article: Madison A.A., Kuzmina T.V. 2019. Early Paleozoic brachiopod larva: true larva, not a juvenile // Invert. Zool. Vol.16. No.1. P.41-47. doi: 10.15298/ invertzool.16.1.05

KEY WORDS: Brachiopoda, ontogeny, larva, protegulum, Paleozoic.

\section{Личинка ранних палеозойских брахиопод: настоящая личинка, не ювениль}

\author{
Анна А. Мадисон ${ }^{1}$, Татьяна В. Кузьмина \\ ${ }^{1}$ Палеонтологический институт им. АА. Борисяка, ул. Профсоюзная, 123, Москва 117997, \\ Poccuя. E-mail: sunnyannmad@yahoo.com \\ ${ }^{2}$ Кафедра зоологии беспозвоночных, Биологический факультет МГУ имени М.В. Ломоносо- \\ ва, Ленинские горы 1-12, 119991 Москва, Россия. E-mail: kuzmina-t@yandex.ru
}

РЕЗЮМЕ: Онтогенез вымерших брахиопод обычно реконструируют по строению их ювенильных раковин. Однако представления палеонтологов об эволюции жизненных циклов брахиопод часто противоречат мнению биологов, гипотезы которых основаны на данных по развитию современных брахиопод. Так, например, в палеонтологической литературе господствует мнение, что жизненный цикл с планктотрофной стадией, плававшей с раковиной и лофофором, является исходным жизненным циклом для брахиопод. В это же время биологи считают, что первичной для брахиопод была настоящая планктотрофная личинка без раковины. В настоящей работе проведен сравнительный анализ литературных данных по строению стадий развития у вымерших и современных брахиопод. Показано, что в раннем палеозое ювенильные раковины брахиопод имели крупный размер и несли на себе рельеф, который 
соответствует расположению щетинконосных мешков у личинок современных брахиопод, что доказывает наличие у ранних палеозойских брахиопод настоящей планктотрофной личинки.

Как цитировать эту статью: Madison A.A., Kuzmina T.V. 2019. Early Paleozoic brachiopod larva: true larva, not a juvenile // Invert. Zool. Vol.16. No.1. P.41-47. doi: 10.15298/invertzool. 16.1.05

КЛЮЧЕВЫЕ СЛОВА: Брахиоподы, онтогенез, личинки, протегулюм, палеозой.

\section{Introduction}

Brachiopods are the relic group of marine invertebrates, which appeared in the Early Cambrian and experienced their heyday during the Paleozoic. The phylum Brachiopoda is divided into three subphyla: Linguliformea, Rhynchonelliformea, and Craniiformea (Williams et al., 1996). The first brachiopods appeared in the Lower Cambrian and belong to Linguliformea and Rhynchonelliformea. In recent years, many attempts were undertaken to reconstruct the ontogeny of the Early Paleozoic brachiopods. Most of them were based on paleontological material (e.g. Popov et al., 2007; Hints et al., 2013; Ushatinskaya, 2016; Bassett, Popov, 2017) except for a few based on the life cycles of recent brachiopods (Nielsen, 1991; Lüter, 2001; Kuzmina et al., 2019). As a result, the conclusion of research undertaken with paleontological material contradicts the biological conclusions. In short, the conflict of theories is as follows. In the paleontological papers the ontogeny of ancient brachiopods is reconstructed based on the molds of the first-formed shell on the umbones of both valves; most paleontologists suppose the Early Cambrian brachiopods had a planktotrophic stage with a shell (e.g., Zhang et al., 2018). However, some biological reconstruction suggests the initial stage of the evolution of brachiopod life cycles to be a true planktotrophic larvae lacking the shell; the adult body plan and the shell formed only after the settlement (Nielsen, 1991; Kuzmina et al., 2019). This stage is absent in recent brachiopods but may be compared with the trochozoan trochophore.

Many fossil brachiopods have first-formed regions that strikingly differ from the first-formed shells of recent brachiopods suggesting that their types of life cycles are not represented in the modern brachiopod fauna. A good example are the Early Paleozoic brachiopods of the subphyla Linguliformea and Rhynchonelliformea, whose first-formed shells were repeatedly described in the literature (e.g., Williams et al., 1998; Madison, 2004; Popov et al., 2007; Ushatinskaya, 2016). Although both subphyla appeared in the Early Cambrian and have living relatives today, their Early Paleozoic firstformed shells strongly differ from that of the modern brachiopods but were identical in the Cambrian and Ordovician.

Here we analyze the literature data on the life cycles of fossil and modern brachiopods in order to reconstruct the life cycle of the Early Cambrian brachiopods based on the structure of their first-formed shell.

\section{Results and Discussion}

\section{Structure of brachiopod juvenile shell}

The juvenile brachiopod shell is divided into three regions that are successively secreted in the ontogeny: protegulum, brephic, and neanic shells (Holmer, 1989; Williams, Brunton, 1997; Zhang et al., 2018). However, the correspondence of each of listed shell regions to certain stage of the shell growth is variously understood by different authors. Here we accept the terminology adduced in Madison \& Kuzmina (2019, in press). The protegulum is secreted simultaneously by the whole mantle surface at the earliest secretory stage and thus lacks any growth markings. The brephic shell grows accretionary and may bear faint growth lines; its microstructure is similar to the protegular mi- 
crostructure. The neanic shell is in fact a transitionary stage to adult shell and differs from the adult shell in the absence of radial ornamentation. Different types of the brachiopod ontogeny are variously reflected on the structure of these juvenile shell regions. The ontogeny of fossil brachiopods may be reconstructed only on the base of the structure of their first formed shells.

Connection of the type of life cycle and the first-formed shell structure in recent brachiopods

Recent brachiopods have four different types of life cycles:

1. In craniiformeans the blastula hatches from the egg envelopes and after the gastrulation transforms into the bilobed lecithotrophic larva with three pairs of bundles of larval setae. The craniiformean larva lacks the shell, turns on the ventral side after the settlement and after that the protegulum and other shell regions are secreted (Nielsen, 1991).

2. In rhynchonelliformeans the blastula hatches from the egg envelopes and after the gastrulation transforms into the trilobed lecithotrophic larva with two pairs of bundles of larval setae. The rhynchonelliformean larva lacks the shell, reverses the mantle lobes after the settlement and after that the protegulum and other shell regions are secreted (Stricker, Reed, 1985; Long, Stricker, 1991).

3. In discinides (Linguliformea) the bilobed lecithotrophic larva with three pairs of long solitary larval setae hatches from the egg envelopes; larval setal sacks are unknown for these brachiopods. At the pelagic stage the discinide larva transforms into the planktotrophic juvenile with the mouth, anus, and lophophore tentacles; the protegulum and brephic shell form at the pelagic stage (Chuang, 1977; Lüter, 2001).

4. In lingulides (Linguliformea) the larval stage is completely absent and their juvenile hatches already with the protegulum and rudiment of lophophore (Yatsu, 1902; Lüter, 2001).

It is generally accepted that the planktotrophic stage with a shell and rudiment of lophophore of recent linguliformeans is a juvenile stage and is not homologous to the larvae of the rhynchonelliformeans and craniiformeans (Lüter, 2001; Kuzmina et al., 2019).

Thus there are two main types of planktonic stages in the life cycles of recent brachiopods: lecithotrophic larva lacking the shell and having bundles of setae growing from the setal sacks (Rhynchoneliformea and Craniiformea) and planktotrophic juvenile with the shell and adult setae (Linguliformea). Both types of ontogeny are variously reflected on the structure of the protegular and brephic regions, which here are referred to as a first-formed shell. In linguliforms the protegulum and brephic shells are formed at the planktonic stage whereas in rhynchonelliforms and craniiforms the shell forms only after settlement. The first-formed shell of linguliforms is about four or five times as large as the first-formed shell of rhynchonelliforms. The difference in size is probably connected with different modes of life: the planktonic linguliform juvenile feeds using the lophophore tentacles and grows in the water column whereas in rhynchonelliforms and craniiforms, the first-formed shell appears before the development of the lophophore and thus its secretion is provided by means of lecithotrophy. Thus the size may be considered as a reliable criterion for distinguishing between the planktotrophic and lecithotrophic stages in the ontogeny (Freeman, Lundelius, 1999, 2005). The presence of bundles of larval setae with the setal sacks reliably indicates the larval stage in the ontogeny. The larval setae are preserved for some time after the settlement in modern rhynchonelliforms and craniiforms and the larval setal sacks seem to be faintly reflected on the relief of the Novocrania anomala juvenile dorsal valve as inflations (Nielsen, 1991, fig. 15C). Thus two main criteria may be distinguished for the reconstruction of the life cycles of fossil brachiopods by their first-formed region: size (large protegulum and brephic shell are considered as evidence of the planktotrophy at the pelagic stage) and relief (presence of molds of the larval setal sacks indicate true larva) (Freeman, Lundelius, 1999; Williams et al., 1998). 
Reconstruction of the life cycle of Early Cambrian brachiopods by their first-formed shell

The Cambrian representatives of Linguliformea (orders Paterinida, Lingulida, Acrotretida, Siphonotretida; Williams et al., 1998; Popov et al., 2009; Ushatinskaya, 2016) and Ordovician representatives of Rhynchonelliformea (orders Orthida; Madison, 2004; Billingsellida; Popov et al., 2007) have large (up to $1 \mathrm{~mm}$ ), similarly structured first-formed shells (for the general scheme for these orders see Balthasar, 2009). The ventral first-formed shell is shaped as two swellings divided by a median groove and the dorsal first-formed shell contains a system of inflations, one central and one to three pairs of lateral bulges. Fig. 1 represents the protegulum and brephic shell and their schematic reconstruction for the paterinide Olenekotreta olenekensis (Ushatinskaya, 1997) from the Cambrian of Siberia (Ushatinskaya, 1997, 2016). This structural plan of the first-formed shell characterizes many Cambrian linguliforms and Ordovician rhynchonelliforms. Judging by the size and location, the inflation in the middle of the ventral valve is possibly a protegulum (Fig. 1A, C). Anterior to the protegulum, the ventral brephic shell is divided by a median groove that runs strictly in the sagittal plane. Williams et al. (1998) reconstructed this median groove as the site of attachment of ventral mesentery. In recent craniids the mesenteries form at the stage of the brephic shell secretion (Nielsen, 1991), which supports the assumption made by Williams et al. (1998). The central inflated lobe on the dorsal first-formed shell is possibly a protegulum (Fig. 1B, D). The protegulum is framed by two pairs of lobes whose location corresponds to the impressions of larval setal sacks on the brephic shell of recent Novocrania anomala (Nielsen, 1991, fig. 15C). The dorsal protegulum of $O$. olenekensis is about three times as large as the ventral protegulum. In many papers (e.g., Freeman, Lundelius, 2005; Popov et al., 2007) the differences in the protegular sizes are interpreted as the evi- dence of the delay in the formation of the mantle ventral lobe. The only recent brachiopods with different timing of formation of the mantle lobes are the craniids (Altenburger, 2013); however, there are no data on the sizes of their protegular and brephic shells and thus such interpretation is still speculative. The brephic shells are equally sized. Williams et al. (1998) was the first to interpret the impressions on the Cambrian dorsal brephic valves as the molds of setal sacks and later this view was shared by all paleontologists working on the ontogeny of fossil brachiopods (Balthasar, 2009; Ushatinskaya, 2016; Zhang et al., 2018). We suppose the short groove located on the dorsal brephic shell between two anterior impressions of setal sacks to be a site of attachment of dorsal mesentery, which forms in recent craniids simultaneously with the ventral mesentery.

The considered first-formed regions are up to $1 \mathrm{~mm}$ wide that is four or five times as much as the eggs of recent brachiopods; probably the large size is evidence of the planktotrophic stage. The presence of larval setal sacks reliably indicates the larval stage with setal bundles in the ontogeny of the Early Paleozoic brachiopods. Thus the size and structural plan of the first-formed shell of the Early Paleozoic brachiopods determine true larva that fed and grew at the planktonic stage but lacked a shell.

However, in many of the cited paleontological papers (Popov et al., 2007; Hints et al., 2013; Bassett, Popov, 2017; Zhang et al., 2018) the Early Paleozoic brachiopod larva is supposed to have a shell at the planktonic stage; according to these authors, the protegulum and brephic shell were formed at the planktotrophic stage and the end of the metamorphosis was marked by shedding off the larval setae and formation of the adult shell. However, the metamorphosis in brachiopods is considered to consist of the folding on the ventral side (Craniiformea) or reversal of the mantle lobes (Rhynchonelliformea); the shell secretion starts at the juvenile stage after the metamorphosis. The rudiment of the mantle developed at larval stages of craniiforms and rhynchonelliforms cannot be considered as the protegulum. Thus the larva 

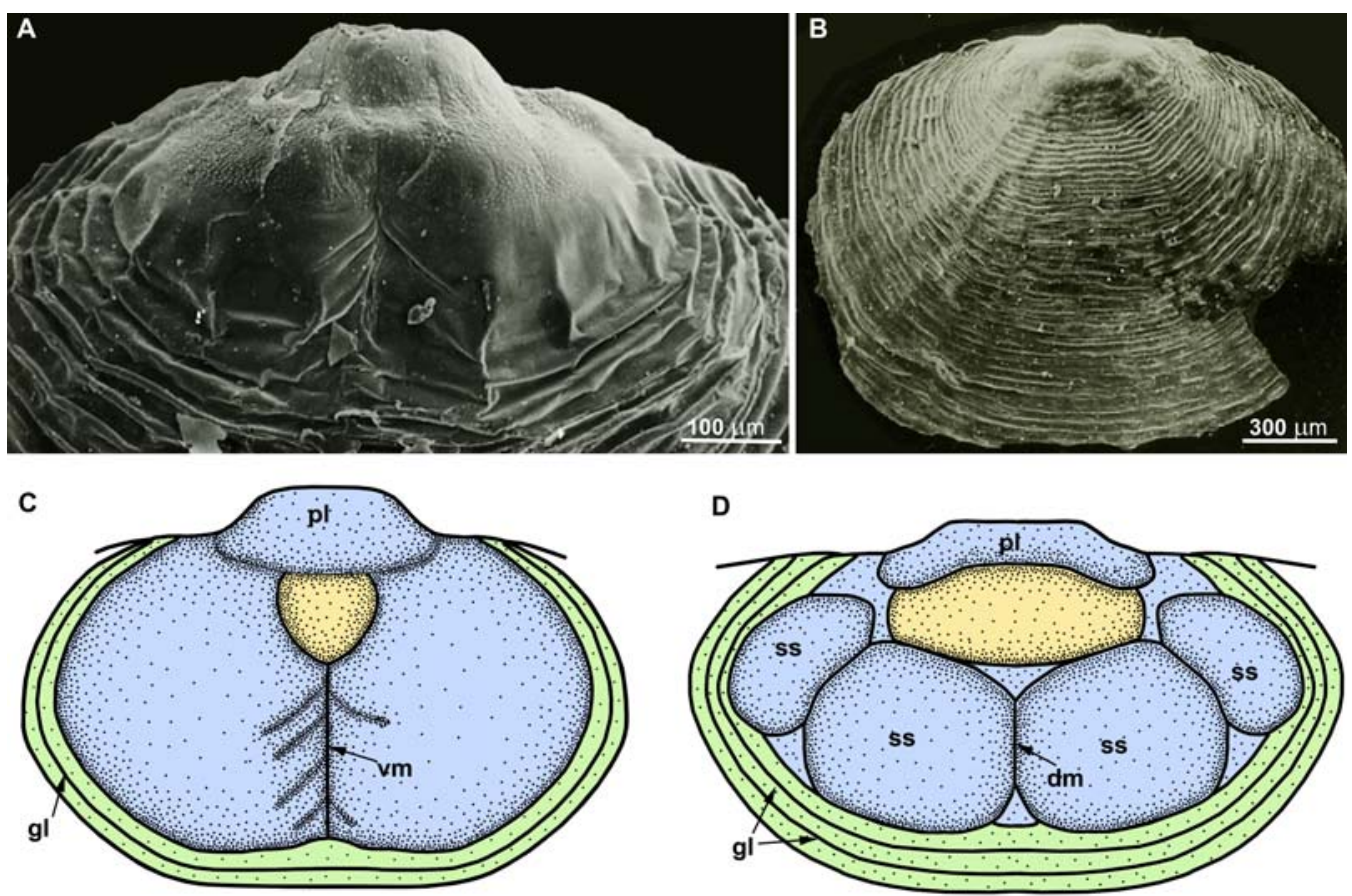

Fig. 1. Paterinide Olenekotreta olenekensis (Ushatinskaya, 1997): A-B - photographs of O. olenekensis by courtesy of G.T. Ushatinskaya: A — specimen PIN, no. 4290/206, first-formed region of the ventral valve; B - specimen PIN, no. 4510/141, general view of the dorsal valve with well-preserved protegulum and brephic shell; middle course of the Kotui River; uppermost Middle-lowermost Upper Cambrian; C-D structural schemes of the first-formed shell regions: $\mathrm{C}$ - ventral valve; $\mathrm{D}$ - dorsal valve (reconstructed from Ushatinskaya, 2016, text-fig. 2c).

Abbreviations: $\mathrm{dm}$ - site of dorsal mesentery attachment, $\mathrm{gl}$ - growth lines, $\mathrm{pl}$ - impression of pedicle lobe, $\mathrm{ss}$ impression of setal sack, vm - site of ventral mesentery attachment; protegulum yellow, brephic shell blue, neanic shell green.

Рис. 1. Патеринида Olenekotreta olenekensis (Ushatinskaya, 1997): А-В - фотографии О. olenekensis, любезно предоставленные Г.Т. Ушатинской: А 一 обр. ПИН, № 4290/206, первично-сформированный участок на брюшной створке; В - обр. ПИН, № 4510/141, общий вид спинной створки с хорошо сохранившимся протегулюмом и брефической раковиной; среднее течение р. Котуй; верхи среднего-низы верхнего кембрия; C-D - схемы строения первично сформированных участков: C брюшная створка; D - спинная створка (по: Ushatinskaya, 2016, рис. 2c).

Обозначения: $\mathrm{dm}$ - место прикрепления дорсального мезентерия, $\mathrm{gl}$ - линии роста, $\mathrm{pl}$ - отпечаток ножной лопасти, ss - отпечаток щетиночного мешка, vm - место прикрепления вентрального мезентерия; протегулюм обозначен желтым, брефическая раковина голубым, взрослая раковина зеленым.

completely lacks the shell and the shell is formed only after the metamorphosis and formation of the adult body plan. The juvenile shells of both recent and fossil brachiopods may be divided into different regions (protegulum, brephic, neanic shells) but irrespectively of the time of the protegulum formation (within the egg envelopes, at the pelagic stage or after the settle- ment), the shell may be developed only in the animal with adult body plan that forms after the metamorphosis in the taxa with indirect development. Therefore, if the brachiopod has a shell at the pelagic stage, it is not a larva, but only a juvenile. Besides, the life cycle with planktonic juvenile is the most evolutionary advanced type of ontogeny that could not be formed at the 
dawn of the brachiopod evolution. Zhang et al. (2018) assumed that the metamorphosis of the Early Cambrian acrotretoids included axial modifications, i.e. the folding but they supposed that the larva metamorphozed already having a shell. Therefore it cannot be regarded as a larva but a juvenile with an adult body plan and could not have undergone any metamorphosis.

It is worth noting that the terms "metamorphic shell" and "metamorphic protegulum" that are used in the mentioned papers make no sense as brachiopods lack shell during the metamorphosis.

\section{Conclusion}

Large first-formed shell with the impressions of larval setal sacks in the Early Paleozoic subphyla Linguliformea and Rhynchonelliformea probably indicates the planktotrophic larva. The life cycle with the planktotrophic larva (not a juvenile!) was probably plesiomorphic for all brachiopods. Thus the paleontological data confirm, based on the biological data assumption, that the initial stage of the evolution of brachiopod life cycles included the planktotrophic larva without a shell (Nielsen, 1991; Kuzmina et al., 2019).

\section{Acknowledgments}

We are grateful to G.T. Ushatinskaya (Paleontological Institute, Moscow) for the photos of the Cambrian paterinids. We would like to thank Yves Candela (National Museums Scotland), whose constructive comments greatly improved the manuscript. This study was supported by the Russian Foundation for Basic Research no 1804-01046 (treatment) and by the Russian Foundation for Basic Research no 19-04-00449 (processing of the paper).

\section{References}

Altenburger A., Wanninger A., Holmer L.E. 2013. Metamorphosis in Craniiformea revisited: Novocrania anomala shows delayed development of the ventral valve // Zoomorphology. Vol.132. P.379-387.

Balthasar U. 2009. The brachiopod Eoobolus from the early Cambrian mural formation (Canadian Rocky Mountains) // Paläontol. Z. Vol.83. P.407-418.
Bassett M.G., Popov L.E. 2017. Earliest ontogeny of the Silurian orthotetide brachiopod Coolinia and its significance for interpreting strophomenate phylogeny // Lethaia. Vol.50. P.504-510.

Chuang S.H. 1977. Larval development in Discinisca (inarticulate brachiopod) // Am. Zool. Vol.17. P.3953.

Freeman G., Lundelius J.W. 1999. Changes in the timing of mantle formation and larval life history traits in linguliform and craniiform brachiopods // Lethaia. Vol.32. P.197-217.

Freeman G., Lundelius J.W. 2005. The transition from planktotrophy to lecithotrophy in larvae of Lower Palaeozoic Rhynchonelliform brachiopods // Lethaia. Vol.38. P.219-254.

Hints L., Popov L.E., Holmer L.E. 2013. Morphology, ontogeny and affinities of the Hirnantian triplesiid brachiopod Streptis undifera from Baltoscandia // Palaeontology. Vol.56. P.961-970.

Holmer L.E. 1989. Middle Ordovician phosphatic inarticulate brachiopods from Västergötland and Dalarna, Sweden // Fossils and Strata. No.26. P.1-172.

Kuzmina T.V., Malakhov V.V., Temereva E.N. 2019. Larval development of brachiopod Coptothyris grayi (Davidson, 1852) (Rhynchonelliformea, Terebratulida) and the evolution of brachiopod life cycles // Invert. Zool. Vol.16. No.1. P.17-40.

Long J.A., Stricker S.A. 1991. Brachiopoda // A. Geise, J. Pearse, V.B. Pearse (eds.). Reproduction of Marine Invertebrates. Vol.6. California: Blackwell Scientific. P. 47-84.

Lüter C. 2001. Brachiopod larval setae - a key to the phylum's ancestral life cycle? // H. Brunton, L.R.M. Cocks, S.L. Long (eds.). Brachiopods Past and Present. Proceedings of the Millennium Brachiopod Congress, 2000. The Systematics Association. Special Volume Series 63. London: Taylor and Francis. P.46-55.

Madison A.A. 2004. The first finds of larval shells in ordovician orthids // Dokl. Earth Sci. Vol.396. No.2. P.488-491.

Madison A.A., Kuzmina T.V. 2019 (in press). The tubelike structures on the juvenile shells of earliest strophomenides and billingsellides as evidences of their life cycles // Lethaia.

Nielsen C. 1991. The development of the brachiopod Crania (Neocrania) anomala (O.F. Müller) and its phylogenetic significance // Acta Zool. Vol.72. P.728.

Popov L.E., Egerquist E., Holmer L.E. 2007. Earliest ontogeny of Middle Ordovician rhynchonelliform brachiopods (Clitambonitoidea and Polytoechioidea): implications for brachiopod phylogeny // Lethaia. Vol.40. P.85-96.

Popov L.E., Bassett M.G., Holmer L.E., Ghobadi Pour M. 2009. Early ontogeny and soft tissue preservation in siphonotretide brachiopods: new data from the Cambrian-Ordovician of Iran // Gondwana Res. Vol.16. P.151-161.

Stricker S.A., Reed C.G. 1985. The ontogeny of shell secretion in Terebratalia transversa (Brachiopoda, 
Articulata). I. Development of the mantle // J. Morphol. Vol.183. P.233-250.

Ushatinskaya G.T. 1997. New Middle and Late Cambrian lingulids and paterinids (Brachiopoda) from the north of the Siberian Platform // Paleontol. J. Vol.31. No.5. P.489-497.

Ushatinskaya G.T. 2016. Protegulum and brephic shell of the earliest organophosphatic brachiopods // Paleontol J. Vol.50. No.2. P.141-152.

Williams A., Brunton C.H.C. 1997. Morphological and Anatomical Terms Applied to Brachiopods // R.L. Kaesler (ed.). Treatise on Invertebrate Paleontology, Part H, Brachiopoda (Revised). Boulder (Co) Lawrence (Ks): Geol. Soc. Am.-Univ. Kansas Press. Vol.1. P.423-440.
Williams A., Carlson S.J., Brunton C.H.C., Holmer L.E., Popov L. 1996. A supra-ordinal classification of the Brachiopoda // Philos. Trans. R. Soc. B. Vol.351. No.1344. P.1171-1193.

Williams A, Popov L.E., Holmer L.E., Cusack M. 1998. The diversity and phylogeny of the paterinate brachiopods // Palaeontology. Vol.41. P.221-262.

Yatsu N. 1902. On the development of Lingula anatina // Journal of the College of Science, Imperial University, Tokyo, Japan. Vol.17. No.4. P.1-112.

Zhang Z.L., Popov L.E., Holmer L.E., Zhang Z.F. 2018. Earliest ontogeny of early Cambrian acrotretoid brachiopods - first evidence for metamorphosis and its implications // BMC Evol. Biol. Vol.18. No.42. P.1-15.

Responsible editor E.N. Temereva 